\title{
Use of covered stents in the field of congenital heart diseases: the role of new players
}

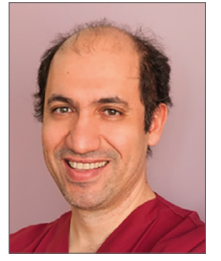

Younes Boudjemline $e^{1,2,3 *}, \mathrm{MD}, \mathrm{PhD}$

1. Necker Hospital-HEGP, Assistance Publique des Hôpitaux de Paris, Paris, France; 2. Université Paris Descartes, Paris, France; 3. Sidra Medicine Heart Center, Doha, Qatar

\section{Introduction}

While devices for closure of abnormal vessels or bare metal stents (BMS) for stenosis relief are commonly available, the number of covered stents (CovStents) remains scarce in the field of paediatric and adult congenital heart diseases (CHD). These stents are used as a bail-out procedure when dilatation or BMS implantation has led to vessel rupture or to exclude some abnormal connections (such as fenestration) or aneurysmal formation ${ }^{1,2}$. The most commonly used covered stent in our field is the CP Stent ${ }^{\circledR}$ (NuMED Inc., Hopkinton, NY, USA). The fragile covering implies a precautious use during ex vivo manipulations and sheath insertion. A few other CovStents coming from the field of interventional radiology have been introduced recently but their use in patients with CHD has not been reported extensively. The aim of our study is to present and describe the use of CovStents in recent practice and define the impact of new players in patients with CHD.

\section{Editorial, see page 974}

\section{Materials and methods}

Consecutive CHD patients receiving CovStents from 01/2016 to $06 / 2017$ were included in the study. The study was approved by an institutional review committee. Patients and/or their parents gave informed consent. During the period, multiple stents were available: the CP Stent, and the LIFESTREAM ${ }^{\circledR}$ stent (Bard Peripheral Vascular, Inc., Tempe, AZ, USA) throughout the period, and the BeGraft stent (Bentley Innomed GmbH, Hechingen, Germany) from February to June 2017. A description of the CovStents is provided in Table 1. Procedural data were collected including indications for CovStents, number and types of stent, efficiency of the covering, the need for post-dilatation and its effect on covering, and success of the procedure. Results are expressed as mean or median value \pm standard deviation and range.

\section{Results}

A total of 94 stents were implanted in 77 patients (median age 1.5 years [0.1-69.7], median weight $36.8 \mathrm{~kg}$ [4.3-87]) including $43 \mathrm{CP}, 38$ LIFESTREAM and 13 BeGraft stents. The use of new CovStents increased with time in parallel with the decreasing use of the CP Stent. Indications for CovStents were as follows: fenestration exclusion $(n=25)$, relief of severe stenosis/vessel occlusion $(n=13)$, Potts creation $(n=11)$, during pulmonary valve implantation to reduce paravalvular leak $(\mathrm{n}=10)$, or as a bail-out procedure

*Corresponding author: Cardiac Catheterization Laboratories, Sidra Medicine Heart Center, Al Luqta Street, P.O. Box 26999, Doha, Qatar.E-mail: yboudjemline@yahoo.fr 
Table 1. Stent characteristics.

\begin{tabular}{|c|c|c|c|c|}
\hline $\begin{array}{l}\text { Type of stent/ } \\
\text { characteristics }\end{array}$ & $\begin{array}{c}\text { Covered CP Stent } \\
\text { (NuMED) }\end{array}$ & LIFESTREAM (Bard) & BeGraft (Bentley) & Advanta V12 (Maquet) \\
\hline Graft material & $\begin{array}{l}\text { - ePTFE (thicker) } \\
\text { - placed externally } \\
\text { - glued at both ends on } \\
3 / 8 \text { of the zig }\end{array}$ & $\begin{array}{l}\text { - ePTFE } \\
\text { - internal and external } \\
\text { - encapsulated in stent }\end{array}$ & $\begin{array}{l}\text { - ePTFE } 0.2 \mathrm{~mm} \\
\text { - placed externally } \\
\text { - double stent struts at the } \\
\text { ends to clamp the ePTFE }\end{array}$ & $\begin{array}{l}\text { - ePTFE } 0.2 \mathrm{~mm} \\
\text { - internal and external } \\
\text { - encapsulated in stent }\end{array}$ \\
\hline Stent material & $\begin{array}{l}\text { Platinum-iridium } \\
\text { Closed cells }\end{array}$ & $\begin{array}{l}\text { Stainless steel (316L) } \\
\text { Open cells }\end{array}$ & $\begin{array}{l}\text { Cobalt-chromium } \\
\text { Open cells }\end{array}$ & $\begin{array}{l}\text { Stainless steel (316L) } \\
\text { Open cells }\end{array}$ \\
\hline Catheter shaft & $\mathrm{NA} / 110 \mathrm{~cm}$ & $80 / 135 \mathrm{~cm}$ & $75 / 120 \mathrm{~cm}$ & $80 / 120 \mathrm{~cm}$ \\
\hline Pre-mounted on balloon & No/Yes (BIB) & Yes (single balloon) & Yes (single balloon) & Yes (single balloon) \\
\hline Available diameters & $\begin{array}{l}12 \text { to } 24 \mathrm{~mm} \text { when } \\
\text { pre-mounted } \\
6 \text { to } 24 \mathrm{~mm} \text { if crimped on } \\
\text { any vascular balloon }\end{array}$ & $\begin{array}{l}-5 \text { to } 12 \mathrm{~mm} \\
\text { - increment of } 1 \mathrm{~mm}\end{array}$ & $\begin{array}{l}\text { Peripheral: } \\
-5 \text { to } 10 \mathrm{~mm} \\
\text { - increment of } 1 \mathrm{~mm} \\
\text { Aortic: } \\
-12 \text { to } 24 \mathrm{~mm} \\
\text { - increment of } 2 \mathrm{~mm}\end{array}$ & $\begin{array}{l}\text { Peripheral: } \\
-5 \text { to } 10 \mathrm{~mm} \\
\text { - increment of } 1 \mathrm{~mm} \\
\text { Aortic: } \\
-12 \text { to } 16 \mathrm{~mm} \\
\text { - increment of } 2 \mathrm{~mm}\end{array}$ \\
\hline $\begin{array}{l}\text { Available lengths in } \mathrm{mm} \\
\text { (numbers in bracket } \\
\text { correspond to stent } \\
\text { diameter) }\end{array}$ & $16 / 22 / 28 / 34 / 39 / 45$ & $\begin{array}{l}2 \\
6 / 37(5 \mathrm{~mm}) \\
16 / 26 / 37 / 58(6,7,8 \mathrm{~mm}) \\
38 / 58(9,10,11,12 \mathrm{~mm})\end{array}$ & $\begin{array}{l}\text { Peripheral: } \\
18 / 22 / 28 / 38 / 58 \\
18 / 23 / 27 / 37 / 57 \\
27 / 37 / 57 \\
\text { Aortic: } \\
19 / 29 / 39 / 49 / 59 \\
(12-14 \mathrm{~mm}) \\
19 / 29 / 38 / 48 / 58(16 \mathrm{~mm}) \\
29 / 38 / 48(18 \mathrm{~mm}) \\
27 / 37 / 48(20 \mathrm{~mm}) \\
37 / 48(22-24 \mathrm{~mm})\end{array}$ & $\begin{array}{l}\text { Peripheral: } \\
16 / 22 / 38 / 59(5,6,7 \mathrm{~mm}) \\
38 / 59(8,9,10 \mathrm{~mm}) \\
\text { Aortic: } \\
\text { 29/41/61 }(12,14,16 \mathrm{~mm})\end{array}$ \\
\hline Sheath compatibility & 8-14 Fr & $\begin{array}{l}\text { Peripheral: } \\
6 \operatorname{Fr}(7 \mathrm{~mm}) \\
7 \operatorname{Fr}(8,9 \mathrm{~mm}) \\
8 \operatorname{Fr}(10,11,12 \mathrm{~mm})\end{array}$ & $\begin{array}{l}\text { Peripheral: } \\
6 \mathrm{Fr}(5,6,7,8 \mathrm{~mm}) \\
7 \mathrm{Fr}(9,10 \mathrm{~mm}) \\
\text { Aortic: } 9-14 \mathrm{Fr}\end{array}$ & $\begin{array}{l}\text { Peripheral: } \\
6 \mathrm{Fr}(5,6 \mathrm{~mm}) \\
7 \mathrm{Fr}(7,8,9,10 \mathrm{~mm}) \\
\text { Aortic: } \\
9 \mathrm{Fr}(12 \mathrm{~mm}) \\
\text { and } 11 \mathrm{Fr}(14 / 16 \mathrm{~mm})\end{array}$ \\
\hline Profile & + & ++ & ++++ & +++ \\
\hline $\begin{array}{l}\text { Bending in crimped } \\
\text { configuration }\end{array}$ & + & +++ & ++++ & ++ \\
\hline Trackability & + & +++ & ++++ & ++ \\
\hline Recoil & Around 4\% & Around $12 \%$ & Around $5 \%$ & Around 6\% \\
\hline Foreshortening & $\begin{array}{l}\text { Around } 5 \% \text { at small } \\
\text { diameters } \\
\text { Up to } 40 \% \text { at } 24 \mathrm{~mm}\end{array}$ & Around 8\% & $\begin{array}{l}3-5 \% \text { up to } 12 \mathrm{~mm} \\
\text { Up to } 26 \% \text { at } 24 \mathrm{~mm}\end{array}$ & Around $11 \%$ \\
\hline $\begin{array}{l}\text { Stent flexibility after } \\
\text { expansion }\end{array}$ & + & +++ & ++++ & ++ \\
\hline Radial force & +++ & ++ & ++++ & ++ \\
\hline Radiopacity & ++++ & ++ & +++ & ++ \\
\hline Kink resistance & +++ & + & ++++ & ++ \\
\hline Overexpansion & Up to $26 \mathrm{~mm}$ & $\begin{array}{l}\text { Up to } 22 \mathrm{~mm} \\
\text { (using } 12 \mathrm{~mm} \text { stent) }\end{array}$ & $\begin{array}{l}\text { Up to } 30 \mathrm{~mm} \\
\text { (using 20-22-24 mm } \\
\text { stent) }\end{array}$ & $\begin{array}{l}\text { Up to } 22 \mathrm{~mm} \\
\text { (using } 16 \mathrm{~mm} \text { stent) }\end{array}$ \\
\hline Manual crimpability & ++++ & ++ & ++ & + \\
\hline Quality of covering & + & ++++ & +++ & ++++ \\
\hline
\end{tabular}

for conduit rupture $(n=4)$, for treatment of intrastent intimal proliferation $(n=9)$, and exclusion of abnormal vascular anomalies $(\mathrm{n}=5)$. Thirty-eight of $51 \mathrm{BeGraft} /$ LIFESTREAM stents were postdilated using a balloon 2 to $6 \mathrm{~mm}$ larger than the labelled diameter. Immediate angiographic evaluation showed no extravasation and excellent function of the covering before and after post-dilatation when performed (Figure 1). At last follow-up (median 1.6 years
[0.9-2.3]), no patient had failure of implanted stents requiring clinical attention or any intervention. One patient had redo catheterisation for creation of a fenestration three weeks after fenestration closure. This patient had a severe enteropathy due to a large thrombus in his total cavopulmonary connection (TCPC). His fenestration was closed to avoid stroke and peripheral emboli, knowing that he will need reopening of the fenestration after heparin infusion. 


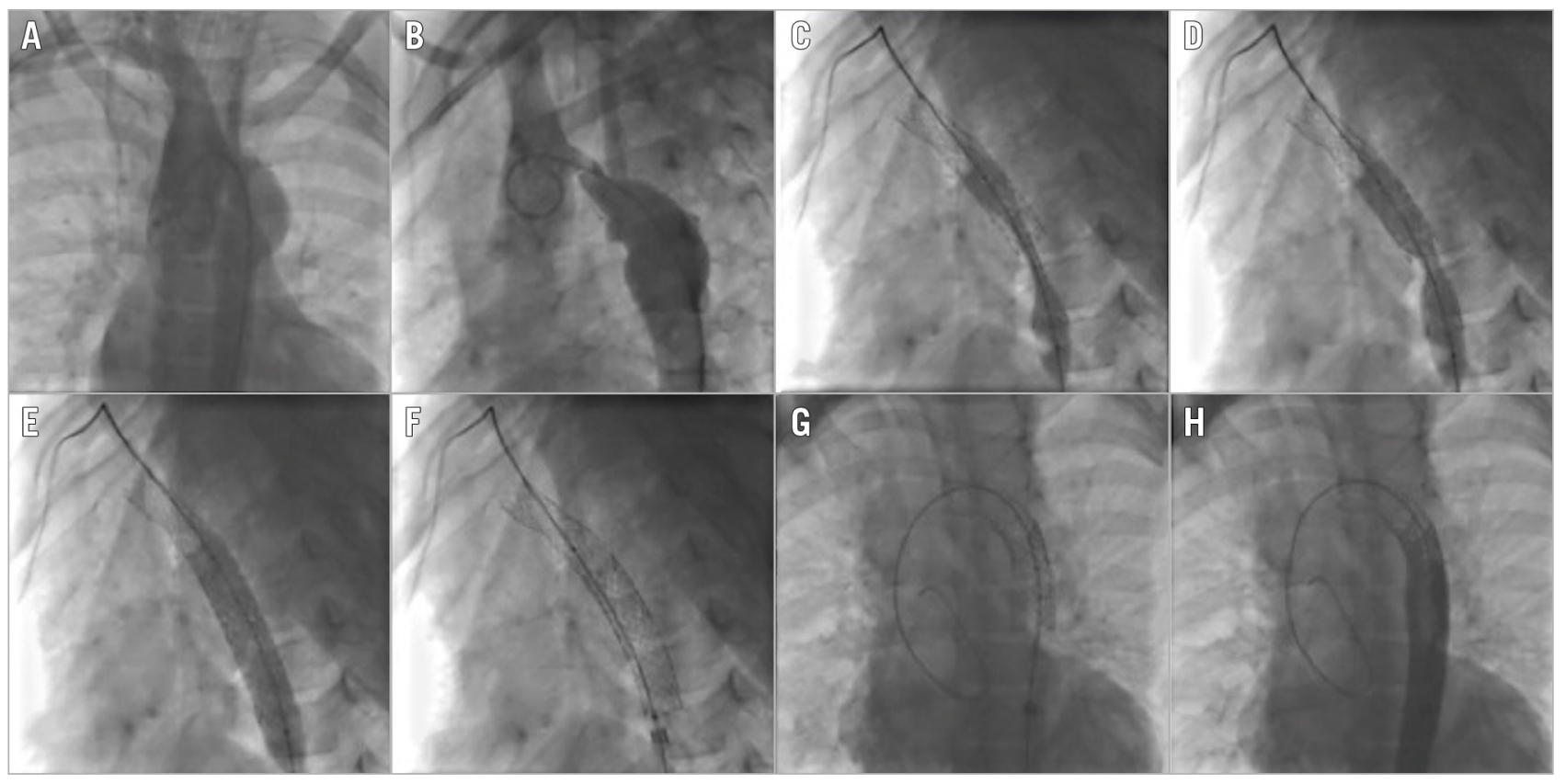

- $\mathrm{C}$

Figure 1. Recoarctation stenting using two Bentley covered stents. A) \& B) Angiograms in LAO and lateral view showing a severe recoarctation of the transverse arch and an aneurysm. C) \& D) Inflation of the second stent at different stages. E) \& F) Aspect of the stent at full inflation (E) and after deflation (F) showing no significant recoil. G) Aspect after post-dilatation of the distal part. H) Final angiogram showing perfect apposition of the stent and exclusion of the aneurysm.

\section{Discussion}

We report our experience with the use of CovStents in recent practice. Until recently, available CovStents (CP stent) were far from ideal because of the poor quality of the covering. This explains our policy to use CovStents mainly as a bail-out in case of iatrogenic vessel damage or to treat a specific lesion that cannot be treated by a BMS. However, the arrival of new game players in that field might change our policy in the future. The superiority of the new CovStents has definitely modified our first choice of stent in situations where a covered stent is needed.

\section{Limitations}

Interventionists in the field are reluctant to use new CovStents because of recent experience with the Advanta ${ }^{\mathrm{TM}}$ V12 (Maquet, Rastatt, Germany). Secondary collapses were reported. The reasons behind this complication are unclear but were attributed to the malapposition of the stent and the important recoil. The sandwich technology used for the covering was proposed in order to explain the poor radial force of the Advanta. The LIFESTREAM stent shares the same technology whereas the covering of the BeGraft stent is similar to the CP Stent, the covering being external only and not embedded in the stent. This might explain why the recoil and radial strength of the BeGraft are comparable to or better than those of the CP Stent. The intrinsic properties of the BeGraft stent exceed those of its competitors. In addition, the BeGraft stent also offers a larger portfolio in terms of diameter and length. For these reasons, since February 2017, the BeGraft aortic stent has been used almost exclusively in situations where the $\mathrm{CP}$ was also a choice.

\section{Conclusion}

In conclusion, the intrinsic properties and covering of BeGraft stents are far better than those of CP Stents. Their use has increased over the years and it now represents the first-line stent used in our unit.

\section{Impact on daily practice}

The CP Stent was until recently the only available covered stent in paediatric cardiology. New CovStents have recently been introduced onto the market (LIFESTREAM and BeGraft). The quality of the covering and the intrinsic properties of the BeGraft explain the reduced use of CP Stents in our laboratory. These new CovStents can be used in daily practice in a wide range of indications.

\section{Conflict of interest statement}

The author has no conflicts of interest to declare.

\section{References}

1. Boudjemline Y, Agnoletti G, Marini D, Bonnet D, Sidi D. [Use of covered stents to occlude extracardiac Fontan fenestration]. [Article in French]. Arch Mal Coeur Vaiss. 2006;99:424-8.

2. Boudjemline Y, Malekzadeh-Milani S, Patel M, Thambo JB, Bonnet D, Iserin L, Fraisse A. Predictors and outcomes of right ventricular outflow tract conduit rupture during percutaneous pulmonary valve implantation: a multicentre study. EuroIntervention. 2016;11:1053-62. 